\title{
Ve Ateş Bizi Tüketiyor romanında benlik bölünmesi ve bilinçdışı labirentlerinde kimlik arayışı
}

\section{Sema NOYAN 1}

\begin{abstract}
APA: Noyan, S. (2020). Ve Ateş Bizi Tüketiyor romanında benlik bölünmesi ve bilinçdışı labirentlerinde kimlik arayışı. RumeliDE Dil ve Edebiyat Araştırmaları Dergisi, (19), 339-354. DOI: $10.29000 /$ rumelide.752350.
\end{abstract}

\section{$\ddot{O} \mathbf{z}$}

Günümüz yazarı Murat Gülsoy’un son romanı Ve Ateş Bizi Tüketiyor (2019), benlik bölünmesi, yabancılaşma, arayış gibi temaları ele alan, postmodern niteliklere sahip bir roman olarak dikkat çekmektedir. Çalışmada, romanın içerik ve biçim özellikleri incelenecektir. İçerik yönünden benlik bölünmesi, rüya ve arayış temaları tahlil edilecek, biçim yönünden ise postmodern nitelikler ve gerçeklik algısı ele alınacaktır. Roman, emekli bir ağır ceza reisinin geçmişi ile bugünü arasındaki bölünmüşlüğünü konu alır. Uzun zaman acı çekmiş, geçmiş hayatını belleğinden silmeye çalışan bir adamın kendi zihninde, hayal, rüya, gerçeklik labirentinde kayboluşu ve benlik bütünlüğüne ulaşma isteği temel izlektir. Bu yolculuk gece vakti, bilinç ve bilinçdışı katmanlarında gerçekleşir. Dolayısıyla romanda teknik olarak rüya, hayal ve gerçek iç içedir. İki benlik de acı, korku, kaçıŞ isteği, yaşama sevinci/isteği gibi duyguları ortak olarak yaşarlar. Kaybolan başkişi, mutsuzluk çektiği hayatında kendini bir hikâyenin içinde sıkışmış ve özgürlüğünü kaybetmiş gibi hisseder. Bu sebeple "kendi hikâyesinden çıkıp gitmek" arzusuyla evden uzaklaşır. Sonrasında paralel olarak kayboluşu ve arayışı bir arada yaşar. Başkişinin kendi hayatına yabancılaşması yoluyla gerçekleşen benlik parçalanması, kayboluşun asıl mânâsını taşır. O zamana kadar insanlardan uzak kalmış, yakınlarını kaybetmiş, evinin ıssızlı̆̆ında yalnız bir adam iken o gece, insanlarla birlikte vakit geçirerek kaybettiği dengesini, bütünlüğünü bulmaya çalışır. Bu kayboluş ileriki yaşlarda ortaya çıkan zihin dağınıklığının da bir sonucu olarak gösterilir. Dolayısıyla okuyucu, olayları yaşlı bir adamın zihninden takip eder. Geceye, rüyalara hâkim olan arzu ve korku duyguları damga vurur. Yaşama sevinci, yeniden hayata dönme isteği ve yaşlılıkla birlikte gelen ölüm korkusu iç içe verilir. Arayış ise, hayatın ateşini yeniden tutuşturmanın bir yoludur.

Anahtar kelimeler: Postmodern roman, benlik bölünmesi, rüya, kaybolma, arayış

\section{In novel And Fire Consumes The Us, self-division and the search for identity in unconscious labyrinths}

\begin{abstract}
A contemporary author Murat Gülsoy's latest novel, And Fire Consumes Us (2019), stands out as a postmodern novel that addresses themes such as the division of self, alienation and quest. In this study, the content and form characteristics of the novel will be investigated. In terms of content, the themes "division of self," "dream," and "quest" will be analyzed, and in terms of form, postmodern qualities and perception of reality will be addressed. The novel is about the dividedness between the past and the present of a retired chief of criminal justice. The main theme is how a man - who has suffered for a long time and has been trying to erase his past life from his memory - gets lost in his
\end{abstract}

$1 \quad$ Dr. Öğr. Üyesi, Karabük Üniversitesi, Türker İnanoğlu İletişim Fakültesi, Gazetecilik-Bilişim Bölümü (Karabük, Türkiye), semanoyan@karabuk.edu.tr, ORCID ID: 0000-0001-5232-8348 [Makale kayıt tarihi: 18.11.2019-kabul tarihi: 20.06.2020; DOI: 10.29000/rumelide.752350] 
mind, in his labyrinth of imagination, his dreams and reality, and his desire to attain personal integrity. This travel occurs at night through consciousness and layers of unconsciousness. So, technically, dreams, imaginations and reality are intertwined in the novel. Both personalities experience feelings such as pain, fear, a desire for escape, the joy of living/desire to live. The protagonist who has been lost feels trapped in a story, and he feels as if he has lost his freedom in his unhappy life. For this reason, he walks away from his home with the desire to "get out of his own story and go away." Then, he experiences the feelings of getting lost and being in a quest simultaneously. The personality disintegration, which occurs through the alienation of the protagonist from his own life, carries the true meaning of being lost. Until then, he was a lonely man who had stayed away from people, lost his relatives, and was alone in the wilderness of his house, but he tried to find the balance and integrity he had lost by spending time with people that night. Such being lost is shown also as a consequence of the disorientation that emerges later in life. So, the reader follows what happens through an old man's mind. Feelings of desire and fear that dominate dreams leave a mark on the night. The joy of living, the desire to come back to life and the fear of death that comes as one gets old are presented in an intertwined way. The quest, however, is a way of re-igniting the fire of life.

Keywords: Postmodern novel, self-division, dreaming, getting lost, quest

\section{Giriş}

Murat Gülsoy'un Ve Ateş Bizi Tüketiyor (2019) romanı, büyük bir acının, ölüm ve yüzleşme korkusunun meydana getirdiği benlik bölünmesini konu alan ve postmodern özellikler sergileyen bir eserdir. Romanda oyun, parodi, pastiş, metinlerarasılık, bilinçdışı labirentlerinde yolculuk (iç yolculuk), imge ve motif kullanımı gibi postmodern niteliklere yer verilmiştir. Modernist romanlarda görülen iç yolculuk teması Gülsoy’un romanının temel izleklerindendir.

20. yüzyılın başında modernist roman, edebiyatın tüm kurallarını ters yüz eder. Özellikle romanın biçim özelliklerindeki yenilikler dikkat çeker. Biçim ve üslup meselesinin ağırlıklı olduğu modernist ve postmodernist romanlarda akla ve rasyonaliteye aykırı her şey birer oyun ve teknik meselesi haline gelebilmektedir. "20. yüzyl postmodern romanının kurgu düzlemindeki en belirgin özelliklerinden biri de oyunsuluktur. Metin, oyunun temel unsurudur. Oyunsu yaklaşım postmodern edebiyatta çeşitli bağlamlarda kendini gösterir: Her şey sanatsal düzlemde oynanan bir oyundur” (Ecevit, 2009: 71-2). İsmet Emre, postmodern metinde ironiyle beraber genellikle de dile özgü oyun kavramının varlığını vurgular (Emre, 2006: 112). Yıldız Ecevit ise oyun kavramını "eğlendiricilik" düzleminde ele alır. Kimi zaman metin, okuru eğlendirecek bulmacamsı bir oyuna dönüşür, kimi zaman da yazar eğlendirici bir konu bulur (Emre, 2006: 114).

Çok katmanlı/çok anlamlı dokusuyla modernist imge, postmodernistlerin tek bir anlamla sinırlı kalmak istemeyen anlayışları doğrultusunda kurgusal çözüm üretmek için uygundur.(...) Ancak postmodern edebiyatın imgesi kimi metinde mutasyona uğrar, tüketim toplumunun medyatik popimgesiyle koşutluk göstermeye başlar, anlam potansiyeli daralır, yüzeyde sıkça yinelenen bir yapı sergiler; kimi yerde stereotipler ve klişelerle bütünleşmiş fetiş nesnelerine dönüşür, postmodern yaşamın uzantısı olur (Ecevit, 2009: 75).

Postmodern edebiyatın yazarı, metnini kurgularken eski metinleri parodi ve pastiş yoluyla kullanır, yeniden yaratır. Başka bir metinden bir motif/imge ya da kişiyi oyun tekniğiyle metnine katar (Ecevit, 2009: 75). "Postmodern metinlerde mekân da yer değiştirir, renkten renge girer, biçim değiştirir, akışkan, şeffaf, ele avuca sı̆̆maz bir görüntü olarak belirir” (Emre, 2006: 183). Dolayısıyla Ve Ateş Bizi 
Tüketiyor romanında, yer altına geçişin kolaylıkla sağlandığı hayalî ya da fantastik mekânlar söz konusudur. Bunun yanında gerçekliğe uygun mekânlara da yer verilir.

Romanda birçok edebî eser ve unsura metinlerarasıllk/pastiş/parodi yoluyla gönderme yapılır. Borges'in labirentleri², rüya/düş ve gerçekle iç içe öyküleri3, Ahmet Hamdi Tanpınar'ın Abdullah Efendi’nin Rüyaları 4 hikâyesi, Huzur5 romanı, Oğuz Atay'ın Tutunamayanlar6, Orhan Pamuk'un Kara Kitap ${ }^{7}$, Aldous Huxley'in Ses Sese $\mathrm{Karş}^{8}{ }^{8}$ romanları, Dante Alighieri'nin İlahi KomedyaCehennem adlı manzum eseri, Asaf Halet Çelebi'nin Mağara” adlı şiiri, Yedi Uyurlar Efsanesi, Pygmalion ${ }^{10}$ miti ilk sirada sayllabilir.

Borges, labirent hakkında çeşitli söyleşilerde şu açılklamaları yapar: Labirent imajı, "şaşkınlık ve kafa karışıklığının en açık sembolü, öyle değil mi? Bu, zihnime çocukken gördüğüm bir gravürden yerleşti, dünyanın yedi harikasının gravürüydü ve içlerinden biri bir labirentti. Daire biçiminde bir labirentti ve etrafında palmiye ağaçları vardı. Her neyse, eğer dikkatlice bakarsam, yakından bakarsam merkezindeki canavarı görebilirim, diye düşünmüștüm. Her nasılsa gravürden korkmuştum ve annem "kitabı sevdiğine göre odana götürebilirsin," dediğinde "hayır, hayır, kitaplıkta kalsın,” demiştim, çünkü canavarın kitaptan firlamasından korkuyordum. Tabiî, ona sebebini söylemedim. Çocuklar çok cekingendir. Bir şeyin olmasından çok korktuğunuzda bunu söylemezsiniz. Gerçekten çok esrarengiz bir resimdi. Bir de İngilizce sözlükte sfenks resmi vardı. O zaman korkularımın üzerine gitmek istemiştim; kendi kendime şimdi "altı" kelimesine bakacağım ve o küçük resmi göreceğim demiștim, sonra açar açmaz kapattım kitabı" Borges’le Söyleşiler. (2009). Richard Burgin (Ed.). Hatice, Esra Mescioğlu (Çev). İstanbul: Paradigma, s.120. "Sürekli şaşkınlık duyuyorum. Şaşkınlığın en bâriz sembolü, hayretin en bâ cc riz işareti labirenttir. O yüzden eserlerimde çok fazla labirent görüyorsunuz, ama kurtulmak için elimden geleni yapacağım; başarabilirsem” (Burgin, 2009: 179). Borges mistisizmi labirentten çıkmak için yegâne yol olduğuna inanıyor (Burgin, 2009: 180).

3 Borges, eserlerinde realitenin illüzyonla iç içe olduğu konusundaki yorumlara şöyle cevap verir: "Bir ayrım yapabileceğimizi sanmıyorum. Çünkü ayrım yapabilmemiz için gerçek olup olmadığımızı bilmemiz gerek. Ve öyle sanıyorum ki filozoflar yaklaşık son 2000-3000 yıldır bu konuda tartışıp didiştiklerine göre hükme varmak bana düşmez. "Gerçekdıșı șey" veya "gerçekdıșı olay" ifadelerini ele alalım -ki bu ifadeler de çelişkili. Çünkü bir şeyden söz edebiliyorsak, hatta hayal edebiliyorsak o şey gerçektir. Tabiî eğer "gerçek" kelimesine başka bir anlam yüklemiyorsanız. Ama bir şeyin nasıl gerçek olmayabileceğini bilmiyorum. Hamlet’in mesela Lloyd George kadar gerçek olmaması için hiçbir sebep göremiyorum” (Burgin, 2009: 109). "Gerçekliği karmaşık bulsam da -aslında sürekli daha karmaşık bir hal aldığını düşünüyorum- kendimi asla bir düşünür olarak görmüyorum” (Burgin, 2009: 111). "Bazen düşlerin tesirinde kalıyorum. Ama yalnızca iki kez rüyalarımı yazdım. Birine Episode of Enemy (Düşmanın Serüveni) adlı bir skeçte yer vermiştim, diğer rüyaya Nors dilinde "Tanrıların şafağı" anlamına gelen Ragnarök adını verim. Bu iki rüya neredeyse olduğu gibi yazılmıştır. Daha inandırıcı hale getirmek için birkaç ayrıntıyı değiştirdim. Bunun dışında farkında olmadan rüyaların etkisi altında kalmıs olabilirim. Edebiyat ve düşlerin ayrı șeyler olduğunu sanmıyorum. Tabiî hayat pek cok kez hayale benzetilmiştir. Ama sanırım bir hikâye hayal ettiğinizde aslında onun düşünü görüyorsunuz, aynı zamanda bunu farkında olarak yapıyorsunuz. Yani düş görüyorsunuz ve düşü yönlendirmeye, ona bir son vermeye çalişıyorsunuz. Düş görmek ve düş gördüğümün farkında olmak benim çok sık yaşadığım bir tecrübe” (Burgin, 2009: 123).

4 Romanda yer alan "Ah Bir Sabah Olsa” başlı̆̆ı, Abdullah Efendinin Rüyaları hikâyesine gönderme yapmaktadır. Benlik bölünmesi yaşayan Abdullah Efendi, sarhoș iken gördüğü olağanüstü ve korkunç sahnelerin sonunun gelmesini ister ve şöyle der: "Ah bir sabah olsa, bu uğursuz gece, hayal, hakikat, kendinden gelen her şeyi beraberinde alıp götürse, ben yine iki ile ikinin dört ettiği dünyada kendimi bulsam” Ahmet Hamdi Tanpınar (2010). Hikâyeler, 8. Bs. İstanbul: Dergâh, s. 42. Abdullah Efendi için de bu gece "en çıplak, en zalim hakikatlerin gecesiydi. Abdullah, her şeyi görecek, her şeyi anlayacaktı" (Tanpınar, 2010: 47).

5 Ahmet Hamdi Tanpınar'ın Huzur (1949) romanında başkişi Mümtaz’ın kendi benliğini gerçekleştirme, mesûliyetini üstlenme vazifesi önemli izleklerdendir. Roman boyunca İstanbul'da gerçekleşen gezi, keşif ve arayış söz konusudur. Bu yönleriyle Gülsoy'un romanıyla ortak özellikler yansıttı̆̆ı söylenebilir. Dolayısıyla Gülsoy’un başkişisi "adam/yaşlı adam” da parçalanan benliğinin peşinde bütün bir gece İstanbul'a çok benzeyen bir şehirde bilinçdış̧ı labirentlerinde, rüya ve hayallerle gerçekliğini yeniden inşa etmeye çalışır.

$6 \quad$ Oğuz Atay'ın Tutunamayanlar (1971) romanı benlik bölünmesini konu alır. Turgut Özben, arkadaşı Selim Işık’ın intihar mektubunu aldıktan sonra , onu yakından tanımak için uzun bir içsel yolculuğa çıar. Romanın ilerleyen sayfalarında postmodern metinlerde sıkça karşımıza çıkan "ikizleşme” gerçekleşir. Turgut Özben, Selim Işık’a dönüşerek kendi benliğini gerçekleştirir.

$7 \quad$ Orhan Pamuk'un Kara Kitap (1990) romanında yeşil tükenmez kalem Celal'den Galip'e geçen yazarlık ve yaratıcılık yeteneğidir. Bkz. Jale Parla (2012). Türk Romanında Başkalaşım. 2. Bs. İstanbul: İletişim, s.244-247. Kara Kitap da yer altına inen insanlar konusuna yer verir. Bedii Usta, kendi yaptı̆̆ 1 ve neredeyse canlı gibi olan mankenlerini vitrinlerden yer altına indirir. "Çünkü artık onların taşıdığı eski giysiler, beğenilmemektedir. Batılı tarzda giyinmek modadır ki böylece Batılı gibi hissedilebilsin. Özgünlüğe saygılı Bedii Usta da buna razı olmadı̆̆ için mankenlerini vitrinlerden çeker. Ayrıca Amerikan filmlerinin etkisiyle değişerek "evlat"larının saflı̆̆ını bozmamak için atölyeden de çıkmak istemez (Parla, 2012: 247).

8 Radyo programcısının şu sözü romanın adına gönderme kabul edilebilir: "Radyoda sadece sesinizle var olabiliyorsunuz. Ses sese karşı" (167).

9 Romanda mağara ve ölülerin birlikteliği, Asaf Halet Çelebi’nin Mağara şiirinde geçen "İçimdeki mağarada ölüler yatar" dizesini çağrıştırır:

Mağara

İçimdeki mağarada

Adres

Kırklareli Üniversitesi, Fen Edebiyat Fakültesi, Türk Dili ve Edebiyatı Bölümü, Kayalı Kampüsü-Kırklareli/TÜRKIYE e-posta: editor@rumelide.com
Adress

Kurklareli University, Faculty of Arts and Sciences, Department of Turkish Language and Literature, Kayalı Campus-Kırklareli/TURKEY e-mail: editor@rumelide.com 
Roman, "zihni dağınık, aklı gidip gelen" yaşlı bir adamın, bir gecenin içinde zaman zaman yer değiştiren ve birbirinin yerine geçen, örtüşen iki benliğiyle yaptığı bir iç yolculuğu konu alır. Yaşlı adam, yaşadığı büyük acılardan kurtulmak ve ölüm düşüncesi/korkusundan uzaklaşmak amaciyla çocukluğunun ve gençliğinin mutlu günlerine dönmek ve içinde bulunduğu zamanın sıkıcı, bunaltıcı havasından uzaklaşarak kendi benliğini unutmak ister. Kötü ve acı geçmişinden kaçmak isteyen yaşlı adamın yaşadığı benlik parçalanması, insanlarla birlikte olma arzusuyla giderilmeye çalışılır. Çünkü "benlik bütünlüğü, bireyin dahil olduğu toplumsal davranış ve deneyimin ilişkisel yapısının bütünlüğüyle oluşturulur" (Mead, 2017: 172).

Bir rüya/hayal gibi yaşanan bu yolculuk aynı zamanda bir arayışın gerçekleştiği, geçmişte ve hâlihâzırda yaşanan büyük acıların ve vicdan azabının etkilerinin dinmesinin arzulandığı, büyük yüzleşmeye sürükleyen bir iç yolculuktur. Romanda geçmiş, şimdi, rüya, hayal ve gerçek, birbirinden ayrılamayacak denli iç içedir. Bir başka deyişle yazar bu yöntemle yaşlı adamın zihninin bulanıklığını teknik açıdan da sezdirmek ister gibidir.

Romanda bölüm adları genelde bir leitmotiv özelliği sergiler: İlk bölümün adı "Kayboldu"dur. Bir arayışın ve bölünmenin hikâyesinin anlatıldığı romanda "kaybolmak, kayıp" kelimeleri farklı biçimlerde çok sık tekrarlanır. "İnsan Bazen Bir Hikâyenin İçinde Sıkışıp Kalıyor" ise romanda istenmeyen, reddedilen ya da huzursuz eden bir hayattan kaçış isteğini anlatır. "Yalnızlık Kötü İnsanlar İyi”; yaşlı adamın benlik bütünlüğünü elde etmek amacıyla insanlarla birlikte olmak, bu şekilde yalnızlığından uzaklaşarak özgürleşmek isteğini tekrarlar. Yalnızlıktan korkma, insanın kendisiyle kalmaktan/yüzleşmekten korkmasıyla da ilişkili olduğu için başkişi, bütünlüğünü insanlar arasında bulunmakta aramaktadır. "Bilinç Kendi Yokluğunu Hayal Edemez”, romanda sıkça tartışılan ölüm korkusuna yer verir. "Üzücü Şeyler Düşünmeyin”, çok acı çekmiş yaşlı adamın o gece benlik bölünmesi aracılığıyla üzüntülerinden uzaklaşma isteğini yansıtır. "Lacivert Gök Kubbeden Yağan Ylldızlar”, romana hâkim olan arzu ve korkuya gönderme yapar. "Ben Neredeysem Gelin Bulun Beni”, romanda bir tezat olarak yer verilen kaybolma, arayış ve bulma eylemlerini yansıtır. "Ama Âşık Oldum", kokinalı kadın ve yaşlı adamın aşklarını sezdirir. "illlegal Matematikçiler", romanda sıkça tekrarlanan kayboluş, vicdan azabı ve ölüm konularını ele alır. "Karanlık Temas", romanda bilinçdışını, geceyi, yer altını temsilen leitmotiv olarak tekrarlanan "karanlık"ın bir sergide kullanılmasını ve yaşlı adamın bir heykel yerine geçmesini anlatır. Gecenin ilerleyen saatlerinde heykel canlanır. "Yalnız Deliler İçin"de delilik ile kendini kaybetme, yaşlılık, benlik bölünmesi arasında ilişki kurulur. "Büyülü Orman”da yolunu kaybeden yaşlı bir adamın, kendi hikâyesinden çıktığı ve sanrılar, hayaller yaşadığı bir geceye yer verilir. "Beni Kandıramazsın", intihar ve ölüm temalarını ele alır. "Gecenin İnsanları", romanın geneline yayılan rüya/hayal atmosferini yakından ilgilendirecek şekilde, rüya, gece ve kaybolmak üzerine kurulur. "Mabed Ağacı”, rüya içinde rüya ve ölüm, “Ölüm Kuyuları”,

kurumuş ölüler yatar
zehirle gülen zümrüt
ve yakut yatak içinde
bir zaman
beni uğurlamaya gelen
haramîler
içimdeki mağarada
bir yığın kitap var
bakınca yakından
tasvirlerin gözleri oynar
ve konuşur
hepsinin yüzleri benim yüzüm gibi
ve gözleri benim gözüm gibi

Asaf Halet Celebi (2009). Bütün Sïrleri, 5. Bs. İstanbul: YKY, s.11.

$10 \quad$ Pygmalion, Kıbrıslı bir heykeltıraştır. Fildişinden yaptığı kadın heykeline âşık olur ve Afrodit’in duasına karşılık vermesiyle heykel canlanır ve Galatea adını alır. Pygmalion ile Galatea evlenip mutlu olurlar.

Adres

Kurklareli Üniversitesi, Fen Edebiyat Fakültesi, Türk Dili ve Edebiyatı Bölümü, Kayalı Kampüsü-Kırklareli/TÜRKIYY e-posta: editor@rumelide.com
Kurklareli University, Faculty of Arts and Sciences, Department of Turkish Language and Literature, Kayalı Campus-Kırklareli/TURKEY e-mail: editor@rumelide.com 
yer altındaki ölüm kuyuları, öldürme, hukuk temaları, "Bu Gece Ölüm Yok”, tanrı, özgür irade, rüya içinde rüya, ölümden kaçış isteği, "Kendini Ustaca Yok Gösteren Tanrı”, ölüm, evlatlarını kaybettikleri için acı içinde rüyalarda evlatlarıyla hasret gideren anne-baba temalarına yer verir, "Ah Bir Sabah Olsa", yaşlı adamın kızının mezarı başında ikiye bölünen benliğini iç konuşmalar yoluyla yansıtır. “Aradığınızı Bulabildiniz mi?”, yaşlı adam, rüya içindeki gece yolculuğunda karşılaştığı (âdeta bilinçdışının labirentlerinden çıkardığı) bütün insanlardan ayrılır. Hepsi bir tekneye binip gider. "Kimliğinizi Görebilir miyim?” ile "yaşlı adam”ı arayan "adam”ı aslında yaşlı adamın kendisi olduğu netleşir ve böylece parçalanan benlik yeniden bütünlüğüne kavuşur. Sadece başlıkların yansıttığı içerikten yola çıkarak ön plana çıkan motiflerin, kaybolmak, ölüm, özgürlük ve kimlik/kendilik arayışı, hak ve hukuk meseleleri olduğu söylenebilir.

Çalışmada, romanın temel konu ve motifleri olan benlik bölünmesi, kimlik arayışı, bilinçdışı, rüya, hayal ve gerçeklik konuları üzerinde değerlendirmelere yer verilecektir.

\section{Benlik bölünmesi ve yabancılaşma}

Romanda benlik/kimlik/kendilik meselesine ağırlık verildiği için benlik kavramı ve benlik bölünmesi hakkında kısa bilgi vermek yararlı olacaktır. Benlik kavramı birey kavramını içerir ve bir bakıma kişiliğin bir uzantısıdır. Ancak benliğin en önemli işareti, benlik algısı ve benlik farkındalığı açısından kişinin kendi hakkındaki tavrını yansıtmasıdır (Kağıtçıbaşı, 2010: 163). "Benlik ancak gerçek kişiler ve şeylerle ilişki içinde "gerçek" olabilir" (Laing, 2010: 140). "Benliğin yarılması, bir halüsinasyon tipinin temelini oluşturur. Benliğin parçalarından biri, genellikle "ben" hissini muhafaza ediyor gözükür. Öteki "benlik" "o" diye adlandırılabilir. Ama bu "o" hâlâ "ben"dir" (Laing, 2010: 156). Mead'ın ifadesine göre bir olay duygusal çalkantılara yol açtığı zaman da bölünmeler gerçekleşebilir. Romandaki benlik bölünmesinin bu türden bir durum olduğu söylenebilir. Mead'a göre, genel bir benliği oluşturan çeşitli benlikler, bir bütün olarak toplumsal yapının çeşitli yönlerine karşıllk gelen genel benlik yapısının farklı yönleridir. Dolayısıyla, genel benlik yapısı, genel toplumsal sürecin bir yansımasıdır (Mead, 2017: 172). Benliğin tamamlanması için gerekli olan şey, grup için ortak olan tavırların oluşturulmasıdır. (...) Birey diğerleriyle etkileşim içine girdiğinde, kendisinde bu ortak tepkiler uyandırıldığı sürece kendi benliğine hayat verir (Mead, 2017: 186-187). Bu nedenle romanda benlik bölünmesi yaşayan başkişi, olayın gerçekleştiği gece, tanımadığı farklı insanlarla diyaloglar kurarak kendini daha iyi hisseder.

Romanda benlik bölünmesini anlatan ilk ve çarpıcı detay, romanın ilk cümlelerinde ifade edilen iki ayrı mutfakta, aynı anda çay hazırlama işidir. Her şey bu anda başlar. Bu an, şimdi midir, geçmiş midir, rüya mıdır, gerçek midir? Net değildir. Buna rağmen, yolculuk, söz konusu ân ile başlar. Bölünme, benliğin birbirinden bağımsız kendilikler/benlikler gibi hareket etmesi şeklinde verilir. İki komşu, iki ayrı mutfakta aynı anda çay hazırlamaktadır: Yaşlı kadın, mutfakta çay hazırladığı sırada, kocasının evden çıktığını fark eder, telaş ve korku ile komşusunun kapısını çalar ve komşusundan kaybolan kocasını bulmasını ister. Kapısı çalınan adam ise, mutfakta baharatlı kış çayı hazırlamak için ısıtıcının başında suyun kaynamasını beklemektedir. Hakkında hiçbir bilgiye sahip olmadığımız adam, eline tutuşturulan kırk yıllık eski bir fotoğrafın yer aldığı kimlik ile sokaklara düşer, yaşlı adamı aramaya başlar. Çalışmada karışıklı̆̆ önlemek amacıyla akşam vakti kapısı çalınan ve ismi verilmeyen kişi, “adam”; kimliğin ismi belirtilmeyen yaşlı sahibi de "yaşlı adam” olarak adlandırılacaktır.

Her şeyin başladığı "o gece", anlatıcı tarafından farklı bir gece olarak tanımlanır. "Yaşlı adam"ı aramaya çıkan "adam", insanlarla temas eder, kalabalıklara karışır, "yaşlı adam”ın gitmiş olabileceği 
mekânlara yönelir, zaman zaman da "yaşlı adam"ın benliğiyle özdeşleşir. Kimi zaman da bu iki benlik/kendilik üst üste geçer, örtüşür. "Yaşlı adam" hakkında bilinmeyen birçok ayrıntı, bu bilgileri nasıl edindiği bilinmeyen "adam" aracılığıyla verilir. "Adam", çeşitli mekân ve ortamlara âşinâ gibi rahatlıkla dâhil olur, kendisine kimlik sorulmaz, "adam" da bu hali çok yadırgamaz. "Yaşlı adam"ın da kendisinden önce aynı mekânları dolaştığına nerdeyse emin olur. "Adam”, bu yolculuk sırasında "yaşlı adam" hakkında insanlardan edindiği kimi bilgileri doğru olarak benimserken, kimilerini de kabul etmez. Dolayısıyla başından beri mutfağında kendisine çay hazırlamakta olan "adam", benlik bölünmesi/parçalanması aracıllğıyla özgürlüğe yönelerek o geceyi kendi için bir arayış ve yüzleşme yolculuğuna dönüştüren "yaşlı adam”ın kendisidir. "Adam" kendinden ötekileştirdiği benliğini temsil eden "yaşlı adam” durumunda kalır. Bu nedenle "yaşlı adam"ın kızının mezarı başındaki konuşmasının iki ayrı benliği temsilen yan yana verilmesi, benlik bölünmesinin somut bir örneği olarak kabul edilebilir. Ancak ilk defa "yaşlı adam"ın kendi dilinden konuşmasına yer verilmesi, bütünlüğün gerçekleşmekte olduğunu da sezdirir. Denilebilir ki "adam" ”n başından beri aradığı, aslında acı, pişmanlık, vicdan azabı, yalnızlık, ölüm korkusu gibi duyguların bezdirdiği kendi gerçek benliğidir. "Adam”a bu ağır geçmişin yükü fazla geldiği için gençliğine ya da çocukluğunun mutlu günlerine dönmek ister. Zaman zaman kurtuluşa ermek ümidiyle ölüm isteği de duyar. Ancak o gece, ölümden ziyade bir keşif gecesidir. Bu nedenle başlıklardan biri de "Bu Gece Ölüm Yok”tur. "Adam/yaşlı adam” olumsuz yakın geçmişini, içinden çıkmak istediği bir hikâyeye benzetir. Çocukluğun mutlu ve kaygısız, sorumluluktan uzak günlerine dönme isteği, o gecenin, özgürlüklerin yaşandığı bir zaman dilimine dönüşmesine neden olur. Dünya, keşfedilmeye hazır bir lunaparktır "adam”ın gözünde. Tipkı çocuklukta olduğu gibi "tesadüf, çakışma ve benzerliklerle karşllaşmak" mümkündür. Çünkü çocuklukta "kelimeler, hayal dünyası aracılığıyla kolaylıkla şeylere dönüşebilir.” Bu nedenle o geceye neşe, coşku ve arzunun hâkim olması istenir. Yine de gecede beklenmedik korkular, yalnızlıklar, kayboluşlar, kaçışlar, vicdan azapları, yüzleşmeye vesile olan unsurlar olarak yer alır. "Adam”n uzak geçmişi ile yakın geçmişi arasında yer alan büyük tezatlar gecede başka tezatlıklara da yol açar. Benlik bölünmesi/bütünlük, rüya/hayal-gerçeklik, ölüm-yaşam, yaşlılık-gençlik, korku-cesaret, özgürlük-esaret, yerin altı-yerin üstü, haksızlık-adalet, kaybetmek-bulmak, heykel-canlanma gibi. Aslında ego savunmaları da, bilinçdışı benliğimize karşı oluşturduğumuz karşı savunmalardan oluşur. Ayrıca, "K. Wilber'e göre her bilinç düzeyi kendine özgü bir bilinçdışına sahiptir. Bilinçdışı bir üstte bulunan bilinç düzeyini ikiye bölerek karşıtlıklar oluşturur. Bu bağlamda psikolojik açıdan düalizm, bilinçdışıyla eşanlamlıdır ve bir anlamda içinde bulunulan halin gölgeleriyle örtüşür” (Merter, 2017: 127). Mustafa Merter’e göre "karşıtlıklar aslında birbirinden ayrılmaz parçalardır, dolayısıyla da çift görme hayaldir. Bu şaşılık sürdükçe gerçek anlamda yaşamak mümkün değildir" (Merter, 2017: 127). "Yaşlı adam", çocukluk ve gençlik yıllarının özgürlük ve coşkusunu arayan "adam”ın ötekileştirdiği benliği haline gelir. "Adam”, yakın geçmişine, benliğine, yaşadığı acıya âdeta yabancılaşmıştır. Bir nevi beğenmediği, sıkıcı bulduğu, yalnızlık ve boşluğa mahkûm edilen hayatından kaçmaktadır. Yalnızlık ve ölüm korkusunun hüküm sürdüğü boş evden "ateş" imgesi ile temsil edilen "hayat dolu" dışarısına kaçmak ister gibidir. Bu kaçış, zaman zaman insanın sıkışıp kaldığı "kendi hikâyesinden kaçıp gitme isteğı" izleği ile verilir. Kaçış, çoğu zaman zihin karmaşıklığı sonucu rüya ve hayale sığınma ile gerçekleşir. Bu arayışta rüyaların da araç olarak kullanılmasının teknik birtakım sebepleri olduğu söylenebilir. Jung'un deyimiyle rüyalar, birtakım karmaşık olayların bileşiminin bir sonucudur ve öznenin psikolojik durumunu yansıtır. Psikolojik durum ise öznenin psişik geçmişinin bir sonucudur. Her insanın geçmişinde psişik "çağrışımları" belirleyen farklı değer unsurları vardır. Jung'un deyimiyle güçlü duygusal etkiler yaratan olaylar, sonraki psikolojik gelişimimiz açısından büyük önem taşır (Jung, 2018: 12). Aslında hikâyenin genelinde insanın kendinden kaçmasının imkânsızlığı da sezdirilmektedir. 
“Adam/yaşlı adam”ın yaşadığı benlik bölünmesini en açık şekilde, gözleri görmeyen, ama insanların sakladıklarını seslerinden anlayan bir öğrenci keşfeder. Başkişinin gençlik günlerine dönme isteği ile yaşının verdiği tecrübe ve acının tezatlığı sezgisel olarak şu şekilde yorumlanır:

Değişken. Kararsız. Bazen, bazı anlarda büyük acılar yaşamış birinin sesi bu diyorum, çok yaşlı biri. Ama sonra kayboluyor bu duygu. Aslında o kadar yaşlı değilsiniz. Hayır, kesinlikle. Henüz genç bile sayılırsınız. Ama iște zaman zaman yoğun bir acının gölgesi düşüyor sesinizin üzerine. Hem acı çekmiş hem de acı çektirmiş birinin sesine dönüşüyor. Sanki acıması olmayan, ilkelerine sıkı sıkıya bağlı, ulaşılmaz bir kişilik. Sonra yumuşacık bir tarafı da yüzeye çıkıyor. Acıyla terbiye edilmiş bir ruhun merhametine sahip. Çok garip. Garip, çünkü birden yok oluyor. Burada hiç var olmamış gibi. Az önce buradaydı ama şimdi? Tamamen yok olmuş, ama siz yine de buradasınız. Başka biri gibi (96-7).

Görüldüğü üzere yaşlı ve genç adamın benliği birbirine karışmış gibidir. Bu yorumlar, başkişinin kendini gerçekleştirmede ve bütünlüğe ulaşmada yaşadı̆̆ı bocalamayı da ortaya koyması açısından dikkate değerdir.

Romanın başkişisi "adam/yaşlı adam”ın yaşadığı benlik bölünmesinin, metinlerarasıllk yoluyla 20. yüzyılın dünyaca ünlü Arjantinli yazarı Jorge Luis Borges’i (1899-1986) de hatırlattığı söylenebilir. Nitekim Borges'in de en sik kullandığı temalardan biri, "ben" ve "benler" konusudur. Borges bu vesileyle "ayna" metaforunu da çok sever. Romanda "adam" arayış yolculuğu sırasında kendini bir otelin bahçesinde bulur. Buradaki süs havuzunda yansımasını görmesi ve radyo programcısı tarafından Chang Tzu'nun kelebek rüyasına atıf yapılması da Borges'e gönderme gibidir. "Adam”, havuzun kenarına oturur ve kendi yansıyan görüntüsüne bakar. Şu sözler, kendine yabancılaştı̆̆ının göstergesi gibidir:

Ürkütücü bir siluetti gördüğüm. Bu ben değildim. Farklı bir zamanın içinden bakan biriydi. Bu dünyada aradığını bulamamış, yosunlu karanlık bir yalnızlığın içine hapsolmuş biri. Elimi suya daldırdım, görüntü dalgalanarak yok oldu. Beklediğimden çok daha ılıktı su. Zaten nasıl bir kış gecesiyse (182).

Borges, bir makalesinde benlik bölünmesi ya da benzeriyle karşılaşmanın eski çağlardan itibaren ölümü hatırlattı̆̆ına inanıldığını dile getirir. Kendi hikâyelerinde de bu temayı sıkça kullanır. Birçok sanatçı tarafından kullanılan benlik bölünmesi ve kendi beni’yle karşılaşma teması kimi zaman ölümün, kimi zaman da dönüşümün göstergesidir."11 Gece boyunca "adam/yaşlı adam”n ölüler dünyasından insanlarla karşılaşması ve onlar aracılığıyla ölümü hatırlaması romandaki ölüm izleğinin

11 “Anlatılan efsaneye göre M.Ö 30o'de yaşayan Chuang Tzu, rüyasında kendisini bir kelebek olarak görür ve uyandığında kelebek olduğunu hayal eden bir insan mi, yoksa insan olduğunu hayal eden bir kelebek mi olduğuna karar veremez" Norman Thomas Di Giovanni (2008). Ustanın Dersi, Borges ve Yapıtları Üstüne. Hayriye Ulas (Cev.). Ankara: ODTÜ Yay., s.62. Borges'in favorisi olan bu hikâye, Borges tarafından da sembolleştirilmiştir (Di Giovanni: 2008: 62). Borges'te ben ve benler konusu zamanla ortaya çlkıyor. Bu konuda yazdığı "Duble" adlı makale bize yol gösterir: "Ayna ve sudaki yansımalardan ve ikizlerden esinlenen ya da kamçllanan Duble düşüncesi pek çok ülkede bulunmaktadır. Pythagoras'ın “Arkadaş diğer bir bendir" ya da Platon’un "Kendini bil” ifadeleri muhtemelen bu düşünceden etkilenerek olușturulmuştur. Almanya'da bu Duble düsüncesine "sizinle aynı yolda yürüyen baska bir insan" anlamına gelen Duppelganger denmektedir. İskoçya'da bir insanı ölüme götürmesi için gelen "fetch" vardır; ayrıca ölümden hemen önce insanın tıpkı kendisi gibi gördüğü düşünülen hayalet için, İskoçca bir sözcük olan "wraith" kullanılmaktadır. Bu nedenle birinin kendisi ile karșlaşması uğursuzluktur. Robert Louis Stevenson'un yazdı ̆̆ı "Ticonderoga" baslıklı lirik trajedi, bu tema üzerinde kurulu bir efsaneyi anlatmaktadır. Rossetti tarafından çizilen (Onlar Kendileriyle Nasıl Tanıştı), iki âşı̆̆ın bir ormanın kasvetli karanlığında kendileriyle karşılaştığı garip bir de resim vardır" (Di Giovanni, 2008: 63-4). "Eski Mısırlılar, Duble yani "Ka" düşüncesinde, bir insanın aynı yürüyüş şekline ve aynı kıyafetlerine sahip tam bir kopyası olduğuna inanırlardı. Sadece insanlar değil, Tanrılar ve yaratıklar, taşlar ve ağaçlar, sandalyeler ve bıçaklar hepsi görünmez olan kendi Ka'larına sahiptiler. Bunlar Tanrıların Duble'lerini görebilen ve kendilerine geçmișten ya da gelecekten haber verilen bazı rahipler dışında kimseye görünmezdi" (Di Giovanni, 2008: 64). "Yahudilere göre, birinin Duble'sinin görüntüsü, yakında beklenen bir ölüme işaret değil aksine, kehanette bulunmak için gerekli güçlerin elde edildiğine yönelik bir kanıttı. Bu açıklama, Gershom Scholem tarafından yapılmaktadır. Talmud'da kayda geçen bir efsane, Tanrı'yı ararken kendini bulan bir adamın hikâyesini anlatmaktadır" (...) "Duble’nin kendimizin diğer bir tarafı ya da zıddı olduğu düşünülür” (Di Giovanni, 2008: 64-65). 
de göstergeleri olarak kabul edilebilir. "Yaşlı adam”ın geçmişiyle yüzleşmesi, ölümü kabul etmesine de vesile olur. $\mathrm{Bu}$ nedenle gece boyu ölümden kaçış isteği ile geçmişiyle yüzleşme isteği paralel yürümektedir.

"Yaşlı adam" içinde sıkıştığı hikâyeden ilk defa o gece cesaret ederek çıkıp gitmek ister. Aslında bu kaçış, iki ayrı benlik için de bir özgürleşme eylemidir. Bu nedenle iki ayrı benliğin örtüşmesi olarak yorumlanabilecek şekilde iki ayrı benlik de dışarı çıktığında gökyüzüne bakıp derin bir nefes alır ve büyük bir neşe ve şaşkınlık hisleriyle dolar. O gece, bir "kayboluş", "arayış" ve "benliğini/kendini bulma" gecesidir.

"Adam" gecenin sonunda çakmağın alevine bakarak "ateş" imgesi üzerinden kendi benliğiyle yüzleşmeye, geçmişini hatırlamaya başlar. İlk aklına gelen, kaybettiği kızının anısıdır. Zihnin karmaşık labirentlerinde rüya ve hayal yolculuğundan uyanmaya hazırlanır:

Az sonra artık kızının var olmadığı dünyaya gözlerini açacak ve Tanrının olması gereken yerdeki boşluğa lanet edecekti. Çok uzun bir an boyunca oradaydı, bir rüyanın içinde... Belki de uyuduğunun bile farkında olmayan bir çocuk-Tanrının rüyasının içinde... Rüya içinde rüya içinde rüya içinde rüya... Kendini ustaca yok gösteren bir Tanrı, çakmağın alevini söndürdü (261).

Görüldüğü üzere gece içinde yaşanılanların rüya atmosferini çağrıştırdığı, anlatıcı yazar tarafından da ifade edilmektedir. Gerçeklik algısı yok olacak şekilde rüya içinde rüyaları anımsatan gece yolculuğu; gerçeği, yaşamı, neşeyi, gücü temsil eden "ateş" imgesiyle yerini tıpkı rüya görülen bir uykudan uyanırcasına gerçeğe bırakır. "Ateş"; rüya, hayal, vehim, sanrı ve korkuları yok eder. Geriye sadece vicdan azabı ve ölümle yüzleşme kalır. Kızının mezarı başında kızının ölümüyle yüzleşen "yaşlı adam”, nihayet bütünlüğe kavuşur:

\begin{abstract}
Ah Bir sabah olsa... Ne kadar hızla yaşlandım. Sonun başlangıca bu kadar yakın olduğunu bilmezdim. Ama sabah hâlâ çok uzak. Her yer halen karanlık, her yer sonsuz ceza. Ben ben miydim? Başka birinin içinde kaybolmuştum. Bir yolculuğa çımıştım ama şimdi dönüş yolunu bulamıyordum. Taşa daha sıkı sarıldım. İçinde bir ateş yanıyordu. Ilık yüzeyine yanağımı yasladım. Onu çok özlemiştim. Kelimelerin, cümlelerin olmadığı bir yerde o şimdi. Yaptığım yanlışların, yaktı̆̆ım hayatların bedelini böyle mi ödemiştim? Cevabı bilmek istemiyordum. Soruyu da bilmek istemiyordum. Artık hiçbir şey duymak istemiyordum. Tek istediğim bu sıcak taşa sarılıp uyumaktı $(265-6)$.
\end{abstract}

Bu sözler, yaşlı adamın duyduğu suçluluk duygusunu ifade ettiği gibi, sevdiklerinin olmadığı bir dünyada neden yaşamak istemediğini de ortaya koyar. Dolayısıyla daha önce de ifade edildiği üzere, ölüm, başka bir açıdan "yaşlı adam” için sevdiklerine kavuşma vesilesidir. Bu nedenle gece boyu ölüm ve yaşam iç içedir. Romanın sondan ikinci bölümü olan "Aradığınızı Bulabildiniz mi” bölümünde, arayış gecesinde karşılaştığı bütün gruplar ve kişilerle vedalaşır. Bu durum, rüya, hayal ve vehimlerin son bulduğu anlamına da gelir. Geriye gerçekliği temsilen sadece "yaşlı adam” kalır. Gece boyu ortada olmayan polisler, nihayet "Kimliğinizi Görebilir miyim" bölümünde yaşlı adamı fark ederler ve ona kimliğini sorarlar, kaybolduğunu anlayınca da onu evine götürmeyi teklif ederler. Roman "kaybolmak" ile başlar ve "bulma" ve "bulunma" yı temsil eden "kimlik"in gerçekliğe kavuşması, sahibini bulması ile kapanır. Böylece "yaşlı adam”, gecede rüya/hayal ve gerçekliğin yer aldığı "arayış" boyunca çeşitli grupların arasına katılmış, ötekileştirdiği ve yabancılaştı̆̆ı benliğine başka insanların gözünden bakarak kendiyle hesaplaşmış ve yüzleşmeyi başarmıştır.

\title{
2.Benliğin peşinde yer altına iniş: bilinçdışının labirentlerinde kaybolma
}


Romanda bilinçdışı önemli bir tema olarak, rüya/hayal/sanrı aracıllğıyla gerçekleşen yer altı yolculukları (iç yolculuk) ile temsil edilmektedir. Bu nedenle romanda yer altına iniş imgesi birkaç kez tekrarlanır. Başkişi “adam/yaşlı adam” iç/bilinçdışı yolculuğuna üç kez fantastik bir şekilde yer altında devam eder. Yer altı kavramı özellikle birçok dinde önemli bir yere sahiptir. Eski çağlardan itibaren birçok din ve gelenekte dünya gök, yer ve yer altı olmak üzere sınıflandırılmıştır. Gökyüzü, aydınlık bir âlem olup ilâhî veya yarı ilâhî varlıkların mekânları; yeryüzü, insanların mekânı; yer altı ise sembolik anlamıyla ölüm olayı ile bedenlerini terk edenlerin göçtükleri öte-âlem olarak kabul edilmiştir. Dolayısıyla yer altı; karanlığı, kötülüğü ve ıstırabı da ifade etmektedir. Böylece yer altı, yeryüzündeki "günahkâr" yaşamın bedelinin ödendiğine inanılan bir mekândır (Bkz. Güneş, 2010: 127-128). Psikanalitik açıdan yer altı, dönüşümün yaşandığı yerler olarak ifade edilebilir. Jung’a göre mağara, yeniden doğuşun gerçekleştiği yer, insanın kuluçkaya yatıp yenilenmek üzere kapatıldı̆̆ı gizli bir oyuktur. Jung, "Yedi Uyurlar" efsanesinden yola çıkarak mağaranın anlamını şöyle açıklar:

Her kim mağaraya, yani herkesin kendi içinde taşıdığı mağaraya ya da bilincin dışındaki karanlığa girerse, kendini önce bilinçdışı bir dönüşüm sürecinin içinde bulur. Bilinçdışına girmesi, bilinci ile bilinçdışının içerikleri arasında bir bă̆ kurmasını sağlar. Bunun sonucunda, kişiliğinde olumlu ya da olumsuz anlamda kökten bir değişim olabilir. Dönüşüm genellikle, yaşam süresinin uzaması ya da ölümsüzlüğe adaylık olarak yorumlanır (Jung, 2017: 66-7).

Birey, yaşadığı yer altı deneyimini takiben kendilik ile buluşur, kişilik hüviyetine kavuşur ve tam anlamılla dönüşüme uğramış birey haline gelir (Güneş, 2010: 134). Görüldüğü üzere "adam/yaşlı adam”ın yer altına inişleri, bir nevi temizlenme, arınma, yüzleşme ve dönüşüm süreçlerini temsil eder. "Adam/yaşlı adam"ın yer altından yer üstüne çıktıktan sonraki şu sözleri, yer altına inişin anlamını destekler niteliktedir:

Ciğerlerimi temiz havayla doldururken zihnimin içindeki tozlu koridorların da tazeleneceğini umuyordum. (...) Kendimi karanlık bir denizin içine bırakmıştım. Bir yerlere doğru sürükleniyordum ve bundan dolayı pişman değildim. Bunca zaman hayatımı yönetmekten bıkmıştım belli ki, şimdi olayların kendiliğinden akıyor olması bana heyecanlı bir yolculuk hissi veriyordu. Evet, zaman zaman korkuyordum ama bu bile iyi geliyordu. Evimdeki güvenli yalnızlığımla, damla damla biriken mutsuzluğumla karşılaştırdığımda bu yaşayacağım son gece bile olsa değerdi. Nihayet kanlı canlı bir insan olmuştu. İnsan var olduğunu ölüme yaklaşınca daha iyi anliyordu (112).

Evdeki güvenli yalnızlık; bilinci, mahremiyeti; evin dışı ve yer altı ise bilinçdışını temsil etmektedir. Dolayısıyla bu yolculuğun büyük bir kısmı, bilinçten bilinçdışına yöneliktir. ${ }^{12}$

Yer altı yolculuklarının üçü de plansız, tesadüfî, gecenin bir yarısında başlar. Böylece, gece yarısı rüyalar aracılığıyla bilinçdışına yapılan yolculukları anımsatır. Rüyalarda olduğu gibi yer altında devam eden arayışa da Jung'un kolektif arketipleri, ölüler, mağara, kuyu, labirent, karanlık, kaybolma hissi, tekinsizlik ve belirsizlik hâkimdir. Yer altına ilk iniş, "adam”ın "yaşlı adam”ın kızının eskiden çalıştığı üniversitenin bodrum katına inişiyle başlar. "Adam" mağaraya benzeyen geniş bir meydanda can çekişenlerin de bulunduğu ölüler topluluğuyla karşılaşır. "Adam”, bu ölülerin, ötekileştirdiği "yaşlı adam"ın yani "ağır ceza reisi”nin mahkûm ettiği insanlar olabileceğini düşünür. Aslında yüzleşmenin, yer altında, en karanlık ve korkutucu ortamlarda gerçekleşmesi tesadüf değildir. Çünkü bilinçdışı ile yer altı, ortak imgelere sahiptir. Romanda yer altı ile ölülerin bir arada yer alması, bilinçdışındaki vicdan azabı ile suçluluk hislerinin bastırılması olarak yorumlanabilir. Rüyalarda bastırılan içeriğin bilinçdışından bilince çıkarken birtakım sembollere bürünmesi gibi yer altındaki "adam/yaşlı adam”ın karşısına çıan unsurlar da birtakım sembollerle ifade edilir. Yerin üstündeki insanlarla bütünleşmek

12 Bkz. Gaston Bachelard (2008). Uzamın Poetikası. Alp Tümertekin (Çev.). İstanbul: İthaki.

Adres Bölümü, Kayalı Kampüsü-Kırklareli/TÜRKIYYE e-posta: editor@rumelide.com 
isteyen "adam", yerin altındaki ölülerle de bütünleşmekten zevk alır. Böylece onlar tarafından bağışlandığını hatta onlarla eşitlendiğini düşünmek ister gibidir. Psikanalitik açıdan yorumlanacak olursa; bilinçdışındaki içeriğin bilince çıkarılarak özgürleşme, rahatlama isteğinin ağırlık kazandığı söylenebilir.

Çetindağ’a göre "Anlatım esasına dayalı türlerde mağara, kuyu, yer altı, mahzen ya da zindan gibi bir yere giriş/iniş başka bir âleme geçişin işaretidir. Gerçek anlamda ve sembolik anlamdaki bu geçiş, bir dönüm noktası olarak kabul edilir. Kahraman, bu kapalı mekânlara kendi isteği dışında girer, buradan ancak kendi iradesi, aklı ile çıkar. Bu sebeple onun mağaradan çıkışı, kendi farkına varışının, kendini buluşunun ispatıdır” (Çetindağ, 2007: 446).

Yerin üstü ile yerin altındaki yolculuğun paralel seyrettiği romanda şöyle bir karşlaştırmadan söz edilebilir:

\begin{tabular}{|c|c|}
\hline \multirow{5}{*}{ Yerin üstündeki/yukarıdaki hayat } & Şimdi \\
\hline & Bölünmüş benlik \\
\hline & Kendini arayış \\
\hline & Gerçeklik/Görünen \\
\hline & Bilinç \\
\hline \multirow{8}{*}{ Yerin altındaki hayat/yer altı } & Geçmiş \\
\hline & Kaçış \\
\hline & Vicdan azabı \\
\hline & Yüzleşme \\
\hline & Görünenin öteki yüzü \\
\hline & Kendini/benliğini gerçekleştirme \\
\hline & Rüya ve hayal \\
\hline & Bilinçdışı \\
\hline
\end{tabular}

\section{Tablo 1}

Görüldüğü üzere yer altındaki hayatın çağrışım yaptığı kavramlar, bilinçdışının özelliklerini hatırlatır. "Ne tuhaf yaşlı komşum yeryüzünde, ben ise yer altında kaybolmuştuk" (215) sözleri ise "adam" ile "yaşlı adam"ın zaman zaman birbirine karışan paralel yolculuklarına işaret eder.

Romanın ana izleklerinden biri olan "kaybolmak" ifadesi, yer altında ölü ya da canlı olan insanlarla da ilgilidir. "Kaybolmak", yer altı insanları için sığınak, kaçış, ölüm gibi kavramları çağrıştırır. "Adam”, yer altında bir an aradığını bulduğunu düşünse de ölüleri görünce "aradığım bu değildi" der. Tüm yaşadıklarına yabancılaşır ve geçmişiyle yüzleşmekten, gerçeklerle karşılaşmaktan kaçınır. Ayrıca o gece ölümden söz etmek ya da ölümle karşılaşmak da istemez.

İkinci yer altına iniş, bir sahaf tezgâhıyla bağlantılıdır. Sahaf tezgâhının ilerisindeki bir koridorun kapısı yer altına açılır. İndiği yer, bir köşkün altında gizli olan kumarhanedir. "Kapısında Yalnız Deliler İçin” yazmaktadır. Kumarhane sahibi, mafyanın eline düşmüş ateşin karşısında ölmüş gibi oturan bir 
mimardır. Bu bölümde de "ateş" imgesi tekrarlanır. "Adam", mimarın yüzündeki ölümü hatırlatan dehşet ifadesinden korkup kaçar. Köşkün sahibi ağır ceza reisinin arkadaşıdır, bu nedenle kumar oynayan adamlar "yaşlı adam" hakkında bilgi verirler.

Üçüncü yer altına iniş, bir elektrik arızasını gidermeye yardımcı olduğu sırada gerçekleşir. Yerin altı çok kalabalıktır. Burada tıpkı bilinçdışında olduğu gibi çeşit çeşit insan ve olay yığını vardır: Elektrik İşçileri, metro inşaatı çalışanları, arkeolog, hapishane kaçkınları. Yer altı, hem yerin üstünün inşası hem de kötülüklerin, suçların üstünün örtülmesi işlevleri ile dikkat çeker. Yer altında hak, hukuk, adalet, haksız yere hapse atılan mahkûmların durumları gibi birçok mesele konuşulur. Ölüm kuyularının varlığından söz edilir ve bir kuyu içine atılmış yığınla cesede rastlanır. Ölülerin giysileri hâlâ üzerlerindedir, dolayısıyla ölümün henüz yeni gerçekleştiği söylenebilir. Görüldüğü üzere yer altı, aynı zamanda suç ve suçluların da bulunduğu yerlerdir. Kimsesiz, gizemli cesetler, hapishane kaçakları, illegal işlerle uğraşan mafyalar yer altında bir araya gelir. Suçluların, kötülüklerin ve cesetlerin yer altında bir araya gelişi, dinlerde yer alan Cehennem kavramını, edebî anlamda da 13-14. yüzyll İtalyan şairi Dante'nin İlahi Komedyası'nı ${ }^{13}$ hatırlatır. Hapishane izleği ile yer altı izleği burada birleşir. İkisi de kapalı kalmayı, ceza çekmeyi, toplumdan uzaklaşmayı, erginleşmeyi ve kötülükleri gizlemesi gibi bazı ortak özellikleri dolayısıyla romanda bir araya getirilmiş olabilir.

\section{Rüya/hayal ve gerçeklik yanılsaması}

20. yüzyıldan itibaren değişen gerçeklik algısı sanat ve estetiği derinden etkiler. 20. yüzyıl romanında dış dünyayı yansıtma yerine, dış dünyadan alınmış gerçek parçacıklarıyla iç dünya bir araya getirilerek yeni bir kurgu tekniği oluşturulur. Aydınlanma Çağı'nın getirdiği bilimsellik, 19. yüzyıldan sonra etkisini yitirmeye başlar ve yerini "belirsizlik/olasllık/görecelik kavramlarının yön verdiği yeni bir doğabilim eğilimine bırakır. Bilim, artık geleneksel edebiyatın fantastik diye adlandırdı̆̆ı türden bir gerçeklik anlayışı sunar" (Ecevit, 2009: 27-37).

20. yüzyılda Freud'un ve Jung psikolojilerinin kişisel ve ortak bilinçaltı tanımları, düşler, arketipler insan gerçeğinin en önemli bileşenleri durumuna gelir. Marcel Proust, James Joyce, Franz Kafka gibi modern yazarlar, bu tersyüz gerçekliği edebiyatın biçim/kurgu/yapı düzlemine taşırlar. Nedensonuç ilişkisi yerine grotesk bir yapıya sahip olan, bilinç yolculuklarının hâkim olduğu, konu bütünlüğünün olmadığı metinler kurgularlar (Ecevit, 2009: 28-29).

Roman boyunca rüya/hayal/gerçek iç içe verilerek roman kişileri ve okuyucu için kaygan bir zemin yaratılır. Böylece şüphe ve belirsizlik arttırılır. Neyin gerçek, neyin sanrı ve düş olduğu bilinmez. Rüya, hayal, zihin karmaşıklığı, simülasyon gibi unsurlar gerçekliğin sorgulanmasına yol açar. Romanda kayboluşun gerçekleştiği geceye iki duygu hâkim olur: arzu ve korku. "Yaşıyor olmanın kendisinden duyulan bir coşkuyla yaşamın geçici olduğunu bilmenin acısı birbirine dolanıyordu” (55) ifadesi, roman boyunca iç içe verilen yaşama sevinci, yeniden hayata dönme isteği ve yaşlllıkla birlikte gelen ölüm korkusunu yansıtır. Aslında o gece salt yaşam isteği dirilir, ölüm ise istenmeyen, korkulan, kaçışı tetikleyen bir tecrübe olarak benimsenir. Arayış, hayatın "ateş”ini yeniden tutuşturmanın da bir yoludur. "Adam/yaşlı adam" elinden yitip gidecekmişçesine o gece yaşama dört elle sarılır. Freudyen

13 Dante, dünyayı kuzey yarım küre ve güney yarım küre olarak iki kısım olarak kabul edenlerdendir. Cehenneme giriş kapısı kuzey yarım küresinde bulunmaktadır. Kuzey yarım kürenin tam orta yerinde Kudüs yükselir. Güney yarım kürenin ortasında bir ada, adanın üzerinde de Araf dağı vardır. Dante, Cehennemi, huni şeklinde tasavvur ve tasvir etmiștir. Kuzey yarım küresinde bulunan bu huninin ucu arzın tam merkezine rastlar. Koninin mihveri yukarıya ve aşağıya uzatılacak olursa bunun bir yandan Kudüs, bir yandan da Âraf Dağı hizasında arzın kabuğunu deldiği görülür. İnce bir yoldan kürenin merkezinden geçerek Âraf dağına ulaşmak mümkündür. Cehennemin içi daire şekkinde dokuz kattan ibarettir. Bu dairelerin huninin ağzından ucuna gidildikçe daralır. Dairelerin her birinde başka günahkâr topluluklar cezalandırılmakta, cezaların şiddeti çevreden, merkeze doğru artmaktadır. Dante, A. (1955). Cehennem. Feridun Timur. (Çev.). Ankara: MEB, s. 54-55. 
bakış açısıyla yorumlanırsa arzu ve korku tam da rüyaya has unsurlardır. Ayrıca bu duyguların gece ortaya çıkması, yine bilinçdışını dolayısıyla rüyayı çağrıştırmaktadır. Romanda kaçış isteği, hayale ve rüyaya sığınma yolu ile yansıtılır. Denilebilir ki romanın başkişi, tıpkı ünlü sanatçı Ahmet Hamdi Tanpınar gibi hayal ve rüya sığınaklarında kendine yeni bir hayat belki de benlik inşa etmeye çalışır. Romanda, rüyanın âdeta bir kurmaca unsuru olarak bu derece önemli bir yer tutması, Jung'un bilinçdışı ve bilinç arasında kurduğu şu ilişkiyle açıklanabilir. Jung’a göre rüyalar, bazen önemli bir içeriği ifade edebilir. Buna rağmen rüyanın sebebi anlaşılmaz, ancak bilinçdışı, bilince nazaran bazı şeylerden haberdar olarak birtakım sonuçlar elde eder. Bilinçdışı kendi düşüncesini içgüdüsel olarak sürdürür (Jung, 2009: 78). Dolayısıyla romanda benlik peşinde yolculuğa çıan başkişi, unuttuğu ya da yükünü taşıdığı düşüncelerini ve anılarını rüya vasıtasıyla yeniden hatırlar.

Romanda yer alan şu sözlerle yaşlı bir adamın aklının gidip gelmesiyle rüya/hayal/gerçeklik ilişkisi arasinda ilgi kurulur:

Her şeyi yanlış anlıyor olsak o kadar büyük sorun olmazdı bence. Asıl sorun bazı şeyleri yanlış anlıyor oluşumuz. Bazı şeyleri. Ama hangi şeyleri? Hangilerini yanlış, hangilerini doğru algıladığımızı bilemiyor oluşumuz asıl sorun. Her şeyi karıştıran bu. Bildiklerimizin hepsi kuşkulu hale geliyor. Güvenebileceğimiz bir referans noktası yoksa eğer... boşluktayız demektir. Aklımıza ne kadar güvenebiliriz. Biraz yorulduğumuzda kolaylıkla yanılabiliyor. Rüyalarda olup bitenlere nasıl da inanabiliyoruz içindeyken. Her şeyin bu kadar değişken olması çok korkutucu. Hiçbir düşüncemizde sonuna kadar güvenememek, hiçbir şeye inanamamak. İşte bütün mesele bu (176).

Öte yandan içinde yaşanılan çağın gerçeklik algısının şüpheye yenik düşüşü de sezdirilir. Belki de bu nedenle radyo programcısı, "yaşlı adam"ın yaşadıklarını rüya içinde kaybolmaya benzetir. "Rüyaların içinde kaybolan bir adamı arıyoruz. Kendi hikâyesinin içinden çıkıp gitmiş bir adamı arıyoruz." sözleriyle ilginç durumu dinleyicilerine duyurur. Tüm bu anlatılanlar dikkate alındığında "Radyo Gecenin İnsanları" programında o gece için "rüya" konusuna yer verilmesi sebepsiz değildir. Radyoda rüyalarla sanrılar arasındaki benzerlikler konuşulur. Nitekim "yaşlı adam”ın bu gece yaşadıkları rüyalara özgü bir atmosferi hatırlatmaktadır. Ayrıca, Radyo Gece'ye tıpkı bir rüyada olduğu gibi kaybolarak gelmesi de rüya atmosferini tamamlar. "Adam" bazen, gerçeğe benzeyen gündelik rüyalarla gerçeği karıştırdığını dile getirir: "Bu akşam başıma gelenler rüya da olabilir, gerçek de.” Jung’a göre bilinç ve bilinçdışı arasındaki denge bozulduğunda, bu durum, rüyalar kanalıyla bireye hissettirilerek dengeyi tekrar kurması istenmektedir. Jung, rüyaların bu yönüyle ruhsal hayatı restore edici özelliğe sahip olduğunu savunur. Ona göre dengenin bozulmasıly ruhsal hayatta meydana gelen tahribatın tamirinde rüyanın önemi büyüktür (Çetin, 2015: 97). Başkişi olan "adam”, gerçeklikle bağı koptuğu ve dengesini kaybettiği zaman gerçeklik'e ait olan kimliği çıkarıp bakar. Kimlik, burada gerçekliğe ait bir referans noktası gibidir. Her şeyin birbiriyle ilgili olduğu, ama kimlik dışında her şeyin kaybolduğu (tıpkı rüya gibi) bu gecede, başından beri aranılan da bir "kimlik"ten ibaret gibidir, yani kendiliktir, benliktir. Dolayısıyla "kimlik" burada da bir leitmotiv görevi görmektedir. Gestalt terapisinin kurucusu Fritz Pearls'a göre insanın ruhsal yapısı, parçalanmışlığın neden olduğu gerilimi gidermek için rüya gibi bazı faaliyetlere girişir. Rüya, bozulmuş ve bölünmüş benliği yeniden bütünlüğe dönüştürme amacı taşır. Rüya, bölünmüşlük halindeki kişiyi uyarır. Bu bağlamda bireyin gördüğü rüyaları, bitmemiş süreçlerin tamamlanması için kendisinden gelen mesajlar olarak değerlendirir (Çetin, 2015: 112). “Adam/yaşlı adam”ın yaşadığı duygu karmaşası da bölünmüşlüğü ve dengenin yitirilişini gözler önüne sermektedir:

Bu yaşadıklarım çok tuhaftı, duygudan duyguya geçiyordum hızla. Korkudan cesarete, tehdit altında olmaktan muktedir olmaya... Bu işte bir gariplik vardı. Bir sinavdan geçiyordum sanki. Dönüp yeniden şehre bakmaya başladım. Korkunçtu, çirkindi ama kışkırtıcıydı. Kendimi boşluğa bıraksam, şehrin üzerinde uçsam diye baştan çıkarıcı bir düşünce geçti aklımdan. Özgür olmanın son şartı bu 
olabilirdi, yaşam denilen esaretin zincirlerini kırmak gerekliydi belki de... Başımı salladım. Hayır... dedim. Beni kandıramazsin (163).

Romanda gerçeklik algısını sorgulatan bir diğer unsur da yaşam simülasyonudur. Simülasyon ile rüya içinde rüya yaşantısına yer verilir. "Adam”, rüya içinde rüya diye tanımladığı nörotanıtımda "yaşlı adam” aradıkça karısı yerine geçen kokinalı kadını bulur. Önce mutlu bir hayata sahipken kayboluş tekrarlanır ve rüya içinde rüyada kokinalı kadın olan karısını kaybeder. Durumu özetlemek gerekirse rüya içinde rüyada kayboluş içinde kaybetme söz konusudur. İçinde yaşadığımız çağda, gerçeklik, her türlü algı oyunlarının malzemesi haline getirilebilmektedir. Dolayısıyla simülasyonun, romanda rüya, hayal, gerçeklik alanlarındaki belirsizliği destekleyen bir unsur olduğu ifade edilebilir.

\begin{abstract}
Baudrillard'a göre, "Simulacra, gerçek varlıkların basit bir sureti yahut imajı olmaktan ziyade onların yerine kendini ikame eden yeni bir gerçekliği ifade eder. Gerçek varlıkların yerine geçen ve hiç durmadan televizyon, bilgisayar, telefon, tablet vb. cihazların ekranlarından izlediğimiz imajlar, temsiller, resimler, semboller, kendi gerçekliklerini empoze etmeye başlar. Gerçek(lik) ile hayal ve imaj arasındaki ayrım giderek belirsiz hale gelir. Gerçekliğin kendi hakikatini yitirerek bir "hiperrealite" haline geldiği yer de burasıdır. Artık normal mânâda gerçeklik ortadan kalkmış, yerini başka bir "şey" almıştır. Bu "şey", hız ve anlık iletişim çağının sunduğu imkânlar sayesinde her gün yeni boyutlar kazanarak gerçekliği âdeta perdelemektedir (Kalın, 2018: 106).
\end{abstract}

Romanda hukuk, adalet, kötülük, duyarsızlık, cinayet gibi sosyal meseleler de ele alınmıştır. Ancak roman diyaloglarında görüleceği üzere insanlığa yakışmayacak çeşitli suçların giderek artması karşısında tedirginlik ve çaresizlik söz konusudur. Lunaparkta bir ateşin başında toplanmış ısınan insanlardan bazıları Tanrı meselesini sorgularken Tanrının uyuduğu ve rüya gördüğüne inandıklarını dile getirirler: Tanrı uyuyan ve rüya gören bir Tanrıdır. Tüm insanlık da onun rüyasından ibarettir. Uyuduğu için kötülüklere müdahale etmiyor. Uyandığında varlığımız sona erecektir. Bizim rüyalarımız ise rüya içinde rüya. Biz aslında rüya görmüyoruz. $\mathrm{O}$ çocuk Tanrının rüyasına dâhil oluyoruz. Bizim rüyalarımızı da o görüyor. Görüldüğü üzere Tanrı problemi de romanın dikkat çeken izleklerinden biri olarak kabul edilebilir. Netice olarak dinî anlamda Tanrı ve kötülüklerin varlığını birbiriyle bütünleştirmekte zorlanan, dinin güvenli zeminini kaybeden insan, pasif bir Tanrı anlayışıyla ihtiyaç duyduğu anlamı ve güvenliği sağlamayı tercih eder. Böyle bir perspektif ile rüya da insanın gerçeklik yanılgısına düştüğü dünya hayatında sığınacağı bir alan haline gelebilmektedir.

\title{
4.Romanın izleksel/imgesel yapısı
}

Modernist ve postmodernist romanın önemli unsurlarından biri de imgedir. Romanda başta "ateş" olmak üzere birçok imge/motif/izlek yer almaktadır. Romanda tekrarlı olarak kullanılan ve içeriği zenginleştiren, anlamı güçlendiren imge ve izlekler şunlardır: ateş, tekinsiz, labirent, ölüm, çakmak, yeşil dolma kalem, kimlik ve rüyayı tamamlayan unsurlar.

Romanın adında yer alan "ateş" bir imge olarak kabul edilebilir. "Ateş", yaşam enerjisini, nefsi, heyecanı ve coşkuyu temsil eder. Örneğin daha ilk satırlarda adam kendini şöyle niteler: "Dışarıdan bakıldığında donuk bir adamım, oysa kafamın içinde düşünceler, hayaller alev alev... Ne yararı var? Bir mağaranın içinde yanan ateş ne kadar yumuşatabilir ki taşı? Mağaranın duvarlarında dans eden gölgelerden geriye ne kalır? Kapkara is. Kül ve toz" (13). Platon'un "mağara” metaforunu hatırlatan bu sözler birbiriyle uyum içindedir: Donuk kelimesi ile mağara/taş kelimeleri arasında ilgi vardır. Tıpkı mağaranın içinde yanan ateş gibi donuk kafanın içinde de düşünceler; hayaller, alevler gibi dans etmektedir. Yani içerdeki coşkuyu temsil eden ateş, hayata küsmüş adamı yeniden hayata bağlayamadığı gibi mağaranın duvarlarını da yumuşatamaz. Sadece toz, kül ve is bırakır. Bu düşünceyi destekleyecek şekilde Hale Torun, Platon'un mağarasının bir yanılsama ya da iç dünyanın tutsaklığını 
temsil ettiğini dile getirir. Bilgiye ulaşmak için ışık ve taş ile temas kurmak gerekir (Torun, 2016: 120). Romanda "ateş" imgesi, çakmağın alevi, ateşi seyreden bir ölü ve ateş başında ısınan ve düşünen insanlar ile verilir. "Ateş", ayrıca zamanı da mekânı da yakar; romanda zaman, bilinçdışı yolculuklarıyla geriye doğru genişler, mekân ise bir geceye sığamayacak kadar çok ve çeşitlidir. Her şey çakmağın ateşinde yok olur.

Romanda korkuya dâir unsurlar, gizemli, fantastik ortam ve insanlar dikkat çekmektedir. Yazar belki de bu gerilimi vurgulamak amacıyla sık sık "tekinsiz" kelimesini izlek olarak kullanır. Tekinsiz durumlar, ortamlar, insanlar, hayaller vs. Yazar özellikle rüya atmosferini ya da rüya/hayal ve gerçekliğin birbirine karıştı ̆̆ı kaygan, ürpertici, labirent niteliği sergileyen zaman, mekân ve olayları "tekinsizlik" izleğiyle somutlaştırmak ister gibidir. Romanın geneline hâkim olan bu "tekinsizlik" duygusu, Kafkaesk diyebileceğimiz bir atmosferi de hatırlatır. Yazar, gizem, korku, dehşet ve endişe içeren durumları ve kişileri "tekinsiz" sıfatıyla karşılamayı tercih eder.

Romanda özellikle gece içinde, yer üstünde ve yer altında devam eden karmaşık, uzun dolaşmalar sırasında Borges'in eserlerinde bir şaşkınlığın göstergesi olan labirente, çağrışımsal olarak gönderme yapılır. Bir yere varmayan ve kayboluşu simgeleyen bu şehir turu, âdeta bir "labirent" içinde sıkışıp kalmış ve yolunu arayan insanı hatırlatır. Bu yönüyle romanda içerik olarak bir "labirent" izleği olduğu söylenebilir.

"Ölüm” izleği ise kocasını arayan yaşlı kadın ve bisikletli adama ait "buz gibi kemikli, yaşlı eller" ile sezdirilir. Kocasının kaybolduğunu haber veren yaşlı kadın, gerçekte "yaşlı adam”ın karısı olabilir. Çünkü karısının yaşadığına dâir bir bilgi verilmez. Huzurevindeki kadın; geçmişte yaşadığı yasak aşkları; bisikletli adam, haksızlık yaptığı hükümlüleri temsil ediyor olabilir. Bisikletli adam, "adam"ın eline nasıl geçtiği bilinmeyen çakmağı ister, ikinci karşılaşmalarında çakmağı almayı başarır. "Çakmak" bu noktada ateşi barındırmasıyla ölümü temsil eden bisikletli yaşlı adamın elinde, yaşama, duyulan özlemi sezdirir. Romanda "ateş" imgesini temsil eden "çakmak" bir leitmotiv olarak orkinosun midesinden birçok şeyle birlikte çıkar. Romanda “çakmak” leitmotivi, Kara Kitap’ta Boğaz’ın sularını çektikten sonra bulunan "yeşil tükenmez kalem" gibi bir oyun tekniği olarak kullanılır. Ayrıca orkinosun midesinden çlkan "yeşil dolma kalem" de metinlerarasılık yoluyla Kara Kitap'a göndermedir.

"Kimlik", arayış olarak da nitelenebilecek iç yolculukta "yaşlı adam"a ait kimlik kartı vesilesiyle gerçekliği temsil eden bir motif olarak kullanılır. "Adam", kendi benliğinden şüpheye düştükçe cebinden çıkardığı kimlik kartına bakar. Bazı insanlar da kimlikteki kişinin fotoğrafına bakarak "adam"a hayret ederler. Açıça söylemeseler de fotoğrafın sahibiyle "adam” benzetirler. Dolayısıyla kimliğin aslında başından beri "adam"a ait olduğu sezdirilir.

Roman boyunca kış mevsiminde olunduğu ifade edilmesine rağmen, "llık hava", "llık ve loş ortamlar" motif olarak tekrarlanır. Dolayısıyla "llık ve loş" ifadeleri, romanın kurgu tekniğiyle alâkalı olarak rüya atmosferine uygundur, ayrıca anne karnına dönüş isteğini de çağrıştırmaktadır.

\section{Sonuç}

Murat Gülsoy'un Ve Ateş Bizi Tüketiyor (2019) romanı çağın estetik, felsefî ve toplumsal birçok meselesini gündeme getirir. Postmodern nitelikler taşıyan roman, postmodernizmin de önemli bir meselesi olan "gerçeklik" konusunu hem içerik hem de biçim aracılı̆̆ıyla ele alır. 21. yüzyll, gerçekliğin 
zeminini kaybetmeye devam ettiği bir çă̆dır. Postmodern estetiğin değişen gerçeklik algısı, romanda rüya, hayal, gerçeklik birlikteliği ile sunulur. Simülasyonun gerçeğin yerine geçmesi, bir nörotanıtım örneği ile eleştirel/ironik bir tutumla sunulur. Romanın konusu olan benlik bölünmesi ve kimlik arayışı, postmodern romanın bireyin iç dünyasına verdiği önemi ortaya koyar. Bireyin kendi iç dünyasına yönelmesi, toplumla bağının zayıflamasına yol açar. Toplumdan uzaklaşmak ise benliğin gerçekleşmesine engel olduğu gibi, toplum bütünlüğünü ve insan ilişkilerini de zayıflatır. Bireyin hayatla ve ölümle dengeli bir ilişki kurmasını engeller. Romanın başkişisi, geçmişinde yaşadığı acılar, vicdan azabı, pişmanlıklar nedeniyle çocukluğunun neşeli günlerine dönmek ister, bu nedenle de gerçeklerle yüzleşmekten kaçarak bilinçdışına sığınır. Bilinçdışı katmanlarında gerçekleşen yüzleşme, aynı zamanda arınma ve dönüşüm için bir fırsatı temsil eder. Gece vakti gerçekleşen bilinçdışı/iç yolculuğunda, başkişi, farklı insanlarla iletişim ve bağ kurmaya ihtiyaç duyar. Yani benlik bütünleşmesinin toplumla bütünleşmesine bağlı olduğunu sezer. Diğer bir deyişle kendilik açısından tamamlanmışlığa ulaşmak için "öteki”ne ihtiyaç duyar. Böylece, bir kaçış ve arayışın gerçekleştiği iç yolculukta başkişi, geç de olsa geçmişiyle ve benliğiyle hesaplaşarak acılarıyla yüzleşir. Romanın sonunda benlik bütünlüğünü elde ederek kendini/kimliğini gerçekleştirir. Dolayısıyla Baudrillard'ın bahsettiği hiper-realite çağına rağmen bireyin toplumdan ayrışamayacağı vurgulanır. Romanda hukuk meseleleri de tartışmaya açılır. Hak, hakikat, yalan, şüphe, hayal, rüya kavramları iç içe verilerek hukuka ve gerçekliğe olan inancın sarsılma tehlikesiyle karşı karşıya olduğu sezdirilir. Sonuç olarak roman, gerek biçim gerek içerik açısından çağa ve bireyin sorunlarına eleştirel bir tutum sergiler, öte yandan, birey ve toplum ayrışmasında bütünleşmeyi esas alan, görünenin ardını araştırmayı vurgulayan çözüm önerileri de sezdirir.

\section{Kaynakça}

Alighieri, D. (1955). Cehennem. Feridun Timur (Çev.). Ankara: MEB.

Bachelard, G. (2008). Uzamın Poetikası. Alp Tümertekin (Çev.). İstanbul: İthaki.

Borges'le Söyleşiler (2009). Richard Burgin (Ed). Hatice, Esra Mescioğlu (Çev.). İstanbul: Paradigma.

Çelebi, A. H. (2009). Bütün Şïrleri, 5. Bs. İstanbul: YKY.

Çetin, Özer (2015). Rüya Olgusu ve Dindarlık Üzerine Bir Araştırma. Bursa: Emin.

Çetindağ, G. (2007). "Türk Kültüründe Mağara Motifi”, 38. Uluslararası Asya ve Kuzey Afrika Çalışmaları Kongresi, ICANAS 38, (10-15 Eylül 2007) Edebiyat Bilimi Sorunları ve Çözümleri içinde C.1. Ankara: 443-455.

Di Giovanni, N. T. (2008). Ustanın Dersi, Borges ve Yapıtları Üstüne. Hayriye Ulaş. (Çev.). Ankara: ODTÜ.

Ecevit, Y. (2009). Türk Romanında Postmodernist Açllımlar. 6. Bs. İstanbul: İletişim.

Emre, İ. (2006). Postmodernizm ve Edebiyat, 2. Bs. Ankara: Anı.

Güneş, S. (2010). "Yeraltı Mekanı Ve Kavramının Toplum Ve İmgelem Üzerine Etkisi”, METU JFA 2010/1 (27:2) :125-139.

Jung, C. G. (2018). Rüyalar. 4. Bs. Aylin Kayapalı (Çev.). İstanbul: Pinhan.

Jung, C. G. (2017). Dört Arketip. 5. Bs. Zehra Aksu Yılmazer (Çev.). İstanbul: Metis.

Jung, C. G. (2009). İnsan ve Sembolleri. 4. Bs. Ali Nahit Babaoğlu (Çev.). İstanbul: Okuyan Us.

Kâğıtçıbaşı, Ç. (2010). Benlik, Aile ve İnsan Gelişimi. İstanbul: Koç Üniv. Yay.

Kalın, İ. (2018). Barbar, Modern, Medenî. İstanbul: İnsan.

Laing, R.D. (2012). Bölünmüş Benlik. Ergün Akça (Çev.). İstanbul: Pinhan. 
Mead, G. H. (2017). Zihin, Benlik ve Toplum. Yeşim Erdem (Çev.). Ankara: Heretik.

Merter, N. M. (2017). Dokuz Yüz Kath İnsan, Tasavvuf ve Benötesi Psikolojisi (Transpersonel Psikoloji). 17. Bs. İstanbul: Kaknüs.

Parla, J. (2012). Türk Romanında Başkalaşım. 2. Bs. İstanbul: İletişim.

Tanpınar, A. H. (2010). Hikâyeler. 8. Bs. İstanbul: Dergâh.

Torun, H. (2016). "Bir Antik Yaşam Tasarımı: Anadolu'da Tünel Kentler ve Uygarlıklar Arası İletişimin İzleri”, Yaratıc Endüstriler Uluslararası Tasartm Sempozyumu (O1-O2 Haziran 2016) Bildiriler Kitabı içinde, Yıldız Teknik Üniversitesi Matbaası, Istanbul: 119-130. 